\title{
Democratische controle
}

Jaap van Manen

'Gegeven de controlerende taak van het parlement, verdient het aanbeveling dat parlementariërs een cursus Elementaire Controleleer zouden volgen.' (Ph. Wallage, 1991)

Bovenstaand citaat is de negende stelling uit een proefschrift van een niet onbekende accountant met dezelfde achternaam als de niet onbekende voorzitter van de grootste fractie in de Tweede Kamer (overigens had ik liever gezien dat deze stelling afkomstig was van de fractievoorzitter).

Als wij minister van Financiën Zalm mogen geloven dan is een cursus Controleleer ook nodig voor Burgemeesters. Wethouders en Gemeenteraadsleden. De leden van de Eerste Kamer Boorsma en Van Muijen vroegen hem kort geleden of hij overwoog het toezicht op de gemeentelijke kredietbanken onder te brengen bij De Nederlandsche Bank (een instelling met 53 afgestudeerde registeraccountants in dienst). In zijn antwoord meldde de minister onder meer dat het toezicht van Burgemeesters, Wethouders en Gemeenteraadsleden (op kredietbanken) voldoende behoorde te zijn. Een duidelijkere steun voor de gedachten van Wallage kan ik mij nauwelijks voorstellen. De minister is overigens, politiek gezien verstandig maar uit een oogpunt van staatsmanschap zeer onverstandig, voorbijgegaan aan de vraag of het toezicht door de gemeentelijke politieke ambtsdragers ook daadwerkelijk voldoende is (onduidelijk blijft zelfs of de politieke ambtsdragers wel beschikken over het instrumentarium dat nodig is voor dat toezicht).

Een cursus Elementaire Controleleer is volgens mij overigens niet voldoende. Voor mensen met politieke functies is een scholing op het brede gebied van de accountancy gewenst. Politici verkeren nu nog steeds in de positie dat zij genoegen (moeten?) nemen met de financieel economische informatie die zijontvangen. Veel mogelijkheden waarover eindverantwoordelijken in het bedrijfsleven beschikken worden hen nog onthouden. Waar topbestuurders en commissarissen eisen kunnen stellen aan de frequentie, de tijdigheid en het aggregatieniveau van de aan hen verstrekte informatie nemen kamerleden nog vaak genoegen met dikke pakketten ambtelijke stukken. De financiële administratie van de overheid is nog altijd op kasbasis. Ondernemers die op een dergelijke wijze hun administratie zouden voeren zouden aansprakelijk worden gesteld wegens wanbeleid.

Verrassingen, in de zin van meevallers en tegenvallers, zijn zowel bij de rijksoverheid als bij de lagere overheden schering en inslag. Privatiseringsoperaties pakken geheel anders wit dan verwacht. Niemand weet hoe groot de tekorten ten gevolge van ontduiking van belasting en premies zijn. Evenmin is bekend welk deel van de belastingopbrengsten het gevolg is van witwasactiviteiten (als voorbeeld moge dienen het gebruik van een wasserette door maffiabonzen om zwart geld te witten. De gefingeerde omzet leidt tot extra omzetbelasting en extra belasting naar de winst).

Prof. Drs. J.A. van Manen RA, vennoot bij de maatschap Coopers \& Lybrand en hoogleraar Accountantscontrole aan de Rijksuniversiteit Groningen. 
Er is nog meer reden voor meer aandacht voor accountancy bij overheidsbestuurders. De overheid is bijna per definitie zeer gevoelig voor fraude en corruptie, gepleegd door overheidspersoneel.

Omdat de relatie tussen inkomsten en uitgaven zwak is dienen bijzondere eisen te worden gesteld aan de beheersing van zowel de opbrengsten als de uitgaven. Daarnaast is de overheid zeer kwetsbaar vanwege haar machtspositie waar het bijvoorbeeld betreft het verlenen van vergunningen en concessies. In dit verband acht ik bepaalde schattingen van Ruimschotel (1993) zeer intrigerend. Op basis van door anderen verricht empirisch onderzoek concludeert hij dat het aantal vermeende en werkelijke gevallen van fraude en corruptie binnen het openbaar bestuur op jaarbasis 367 bedraagt terwijl het aantal vermeende gevallen van corruptie bij bedrijven op jaarbasis op 262.500 wordt geschat (het cijfer bij de overheid betreft fraude en corruptie en het cijfer bij het bedrijfsleven uitsluitend corruptie).

Deze cijfers kunnen twee dingen betekenen:

- ambtenaren hebben een veel hogere integriteit dan werknemers van het bedrijfsleven;

- de pakkans bij corruptie bij de overheid is veel kleiner dan die in het bedrijfsleven.

Over de eerste mogelijkheid durf ik mij niet uit te spreken. Als ik dat zou doen zonder het eerst te onderzoeken zou ik alle betrokkenen te kort doen. Als ik het er voorlopig mee eens ben zal het bedrijfsleven verontwaardigd reageren. Als ik het verwerp zullen de ambtenaren zich tekort gedaan voelen. Dat de detectiesystemen bij bepaalde onderdelen van de overheid tekort schieten staat voor mij echter vast. In de betere delen van de in het bedriffsleven gangbare procedures, zoals financieel economische bewaking van projecten, leveranciersselectie bij uitbesteding en dergelijke schieten op veel plaatsen binnen de overheid tekort. Machtsconcentratie bij sleutelfunctionarissen zoals de gemeentesecretaris of een bepaalde wethouder is niet overal uitgesloten. Intelligente leveranciers van de overheid weten de zwakke plekken makkelijk te vinden.

Kortom, als politici worden bijgeschoold op het gebied van accounting en control dan zullen zij zich beter bewust worden van de moeilijkheden en de mogelijkheden op het gebied van financieel beheer. Zij kunnen dan concreet inhoud geven aan hun controlerende taak. Dat zal vergaande gevolgen hebben voor de wijze waarop één en ander bij de overheden geregeld wordt. Het zal onze democratie versterken!

\section{I T E R A T U U R}

Ruimschotel, D., (1993), Corruptie en fraude in Nederland suggesties voor management en beleid, Gouda Quint, Arnhem, pagina 23.

Wallage, Ph. (1991), Methodiek en Mate van structuur, (de bijgevoegde stellingen), Bilthoven

Praktijk registeraccountants/NIVRA Gids 1994, NIvRA, Amsterdam

Het Financieele Dagblad, 17 januari 1995, DNB onderzoekt gemeentelijke kredietbank. 